\author{
Mirosław ŚMIESZEK ${ }^{1}$ \\ Mirosław LIANA ${ }^{2}$ \\ Mariola NYCZ ${ }^{3}$
}

\title{
THE SIZE OF PUBLIC PASSENGER TRANSPORT AND THE NUMBER OF PASSENGER CARS IN POLAND AND SLOVAKIA
}

The increase in wealth of the society leads to an increase in the number of possessions. Nowadays, one of the basic goods is our own vehicle. Starting from the second half of the twentieth century a passenger car has become the own means of transport in Europe. The development of the automotive industry is critical for the changes taking place in the way of satisfying transport needs. The increase in the number of cars in society usually leads to a lower demand for public transport services.

The paper is a comparison of the size of the public transport of passengers and the number of passenger cars in two bordering countries, i.e. in Poland and Slovakia. The available data collected by the statistical offices of both countries were used in the analyses. The data covered the years 2007-11 and related provinces and regions in Poland and Slovakia. In order to compare with each other the studied variables, these data were referred to the size of the population in the regions.

To study the relationship between variables the correlation analysis as well as linear regression were used. The conducted analysis shows that the growth of the automotive industry has contributed to the decline in the number of public passenger transport in both countries. For each country this relationship was described by the linear regression equation. In addition, for both countries there were determined linear trend equations of the studied variables and demonstrated the existence of analogous trends in the regions. Also there were shown some differences between regions and countries, which are expressed mainly in the values of variables, and the pace of change.

Keywords: public passenger transport, a passenger car, province, variables, correlation analysis and linear regression.

\section{INTRODUCTION}

The increase in wealth of the society leads to an increase in the number of possessions. Nowadays, one of the basic goods is our own means of transport. Having your own personal means of transport results from the need to meet ever increasing individual transportation requirements. Starting from the second half of the twentieth century a car has become a very popular mean of transport in Europe. The increase in the number of cars in society can lead to a reduced demand for public transport.

\footnotetext{
${ }^{1}$ Mirosław Śmieszek, DSc, PhD, Eng., Associate Professor, the Rzeszow University of Technology, al. Powstańców Warszawy 8, 35-959 Rzeszów, tel. 17 8651593, e-mail: msmieszk@prz.edu.pl (Corresponding Author)

${ }^{2}$ Mirosław Liana, PhD, The Rzeszow University of Technology, The Faculty of Management, al. Powstańców Warszawy 10, PL 35959 Rzeszów, e-mail: mliana @ prz.edu.pl.

${ }_{3}^{3}$ Mariola Nycz, MSc, The Rzeszow University of Technology, The Faculty of Management, al. Powstańców Warszawy 10, PL 35959 Rzeszów, e-mail: m_nycz@prz.edu.pl.
} 
In the paper it was analyzed how the size and the number of passenger cars in Poland and Slovakia in the period 2007-11 developed. In order to eliminate the effect of population size of the two countries the following variables: number of passengers per 1000 inhabitants and the number of passenger cars per 1000 inhabitants were applied. There were also studied the differences which exist in various regions of the two countries and between the countries.

The analysis was based on the data collected by the Central Statistical Office in Poland and the Statistical Office of the Slovak Republic. To study the relationship between variables the linear regression and correlation analysis was applied (see: R. R. Wilcox ${ }^{4}$ ).

\section{PUBLIC TRANSPORT}

One of the main factors determining the economic development of the country is transportation. Public transport is an area of the economy. Modern transport infrastructure can provide the effect of diffusion of the main centers of economic growth of the country on those parts which - due to the lack of adequate access government - are in a state of stagnation. Properly organized transport and following the innovations transport infrastructure strengthen the competitiveness of the state's economy and its consistency, not only spatial, but also economic and social one. The research on transport in Poland in terms of qualitative and quantitative terms, in relation to the developed European economies, clearly illustrates the disparities which are formed between the two countries.

Without effective functioning transport one cannot talk about full advantage of the potential of the economy and education. Low quality of both these international connections, as well as local ones, adversely affect the mobility of the population and the poor effects of trade and is a very significant barrier to the development of trade and services.

The issue of passenger transport meets with the problem of vague terminology. Such an activity is referred interchangeably as public transport, within the agglomeration, public, local, municipal or passenger. Often as a synonym for the word of transport the term communication is used. ${ }^{5}$

Development of the proper communication system in cities requires large expenditure allocated to infrastructure, including fleet vehicles. In order the system could encourage the use of public mass transport it needs also, in addition to a number of different factors,some kind of encouragement with an attractive price. ${ }^{6}$ Properly functioning public mass transport is a vital component of the social infrastructure that enables sustainable development.

Conducting appropriate actions to manageeffectively the flow of people in urban areas is a task for practitioners and theorists dealing with issues of urban logistics. According to

\footnotetext{
${ }^{4}$ R. R. Wilcox, Applying Contemporary Statistical Techniques, Amsterdam: Academic Press, 2003, s. 173-206.

5 J. Gadziński, Ocena dostępności komunikacji przestrzeni miejskiej na przykładzie Poznania, Bogucki Wydawnictwo Naukowe, Poznań 2010, s. 17-18.

${ }^{6}$ A. Drewnowski, A. Wysocka, Możliwości rozwoju zintegrowanych systemów kolejowo-drogowych pasażerskiego transportu regionalnego w świetle nowej ustawy o publicznym transporcie zbiorowym, Zeszyty Naukowe Politechniki Śląskiej, Seria: Transport z. 75, Gliwice 2012, s. 22.

${ }^{7}$ T. Bartosiński, Cel i zakres ustawy o publicznym transporcie zbiorowym, [w:] Materiaty konferencji ,Plan transportowy w ustawie o publicznym transporcie zbiorowym"(Warszawa, 25 XI 2009), SITK Oddział w Warszawie, Warszawa 2009, http://siskom.waw.pl/nauka/konferencje/20091125/publikacja_calosc.pdf, s. 1 .
} 
the opinion of the European Economic and Social Committeefrom 2007 which shows the proposals for transport in metropolitan areas, the worrying fact is a fast decline of collective public transport and an excessive growth of car traffic in cities. The Committee recommends the need for actions affecting the attractiveness and development of public transport. ${ }^{8}$

The task of the public authorities is a gradual increase of its involvement in the provision of public transport services in urban areas. At the beginning, in the time of application of the omnibus as a means of transport, the market was very competitive and the involvement of local authorities was limited to the issuance of licenses and possible enforcement. Today the situation is completely different. In retrospect, the development of urban public transport market can be divided into three stages:

- Stage I - associated with the creation of the first transport companies characterized by high dynamics and market instability;

- Stage II - associated with the formation of mergers, agreements and consolidation in order to increase profits and achieve stability on the market and the long term functioning. Entrepreneurs were looking forward to create a monopoly on the market;

- Stage III - which is a period of significant involvement of public authorities and high interference. ${ }^{9}$

Undertaken measures, which are used to achieve objectives related to integrated transport policy and land use in cities, are aimed at three groups including:

- development of the city in accordance with the course of the route characterized by the best service by public transport;

- introducing difficulties in the use of private cars in the central parts of cities;

- shortening the length of routes to those which are the most popular destinations among passengers. $^{10}$

Introduction of modern means of transport is primarily associated with the reduction of transport costs of service and ensuring reliabilityand convenience for passengers as well as its safety while traveling. Technological changes are generally associated with the process of diffusion. The process of diffusion of technology means the gradual improvement of inventions and innovations. This process is related tothe development of human skills necessary for the use and application of new techniques to improve the old technology and industry. Some significant market features which are a measure of the rate of adoption of new technologies have a great influence on the diffusion. ${ }^{11}$

\section{CHANGES CHARACTERISTICS IN PUBLIC TRANSPORT}

Among the currently existing systems of public transport, it is the urban transport which has the most stable position in the transport system. The awareness of the needs of its maintenance and the need for its continuous development is also growing. The rapid

\footnotetext{
${ }^{8}$ Opinion of the European Economic and Social Committee on transport in urban and metropolitan areas (exploratory opinion), TEN/276-CESE615/2007, Brussels 2007.

${ }^{9}$ Á. Costa, R. Fernandes, Urban public transport in Europe: Technology diffusion and market organization, "Transportation Research" Part A 46 (2012), s. 269-284.

${ }^{10} \mathrm{~J}$. Malasek, Pakiety wdrożeniowe koordynacji miejskiej polityki transportowej z polityka zagospodarowania przestrzennego, „Transport Miejski i Regionalny”, nr 12, 2011, s. 13.

${ }^{11}$ Á. Costa, R. Fernandes, op. cit., s. 269-284.
} 
growth of urban areas, the negative effects of the increasing vehicular traffic are the results of an increased number of accidents, increased air pollution and congestion are the impetus for the construction of a functioning public passenger transport. ${ }^{12}$

In Western European countries already in the 50s of the twentieth century the phenomenon of a steady decline in the size of passengers using public transport, mainly on local railway lines was observed. In Poland, this trend appeared after 1990 as a result of the rapid development of the automotive industry ${ }^{13}$. Over the last two decades the number of passenger transport by bus decreased almost fourfold. Among other reasons for such a drastic decrease in the size of transport there should be distinguished the following:

- competition from other carriers;

- poor quality of services, low level of modernization of means of transport;

- unsuitable offer to the needs of the transport of passengers;

- removal of unprofitable lines, destabilize profitable lines;

- lack of a coherent communication system on a scale of different areas (region, county, or municipality and country );

- low price competitiveness relative to private means of road transport. ${ }^{14}$

According to Eurostat data for 2010, the leading country in the bus transport measured in kilometers is Hungary, where the share of the transport in all transport amounts to 25.1 percent. For the EU the figure is 8.8 percent. Poland is classified into one of the last in this respect, with the result of 6.4 percent.

The level of motorization is one of the statistical measures describing the state of transportation in the country, region or city. Definitely a better measure would be to use the distribution into transport tasks of individual means of transport and an average trip length of inhabitants . Unfortunately, only some local governments collect such data. ${ }^{15}$

The worrying aspect is the dominance of road transport in passenger transport in the United States (85\%) and the European Union (83\%). The cost of congestion phenomena is estimated by European Union at $1.5 \%$ of GDP. This phenomenon limits the bandwidth for European routes, and it is often the cause of significant delays on the routes, as well as adversely affects the size of transport costs. ${ }^{16}$

Among European countries, the largest share of car travel in the structure ratio of $91.1 \%$ is characterized by Lithuania. This fact is surprising since countries such as Spain and Germany (with the highest motorway networks - the fourthand second in the world), and France (the longest network of public roads in Europe) are not in the forefront of this sheet. Poland is the runner of the classification, the percentage is $88.4 \%$. It should be added that the motorization rate in our country is increasing. Slovakia, in turn, is a country characterized by one of the lowest shares of passenger cars in the structure of travel

\footnotetext{
${ }^{12}$ A. Drewnowski, A. Wysocka, op. cit., s. 21.

${ }^{13}$ Ibidem.

${ }^{14}$ W. Zdanowski, Rozwój czy regres przyszłości transportu publicznego w Polsce i na Dolnym Śląsku w perspektywie 2020, Instytut Rozwoju i Promocji Kolei, Wrocław 2012, s. 26.

${ }^{15}$ M. Beim, Europejskie trendy w transporcie miejskim i regionalnym, [w:] Materialy z konferencji „Przyszłość transportu publicznego - perspektywa regionalna $i$ europejska" (Wrocław, 5 XII 2012), http://www.wspolnesprawy.pl/uploads/Beim_trendy_w_transporcie.pdf, s. 5-6.

${ }^{16}$ M. Mindur, Transport pasażerski $w$ Stanach Zjednoczonych $i$ Unii Europejskiej w latach 1990-2010, „Transport Miejski i Regionalny”, nr 7-8, 2011, s. 42-44.
} 
(77.8\%). To the following there are classified only Hungary $(63.1 \%)$ and the Czech Republic (73.7\%). ${ }^{17}$

In the next chapters it was checked how the size and the number of passenger cars has developed in Poland and Slovakia in recent years.

\section{DATA ANALYSIS FOR SLOVAKIA}

Data on the number of passenger cars per 1000 inhabitants are presented inTable 1.

Table 1. Number of passenger cars per 1000 inhabitants in Slovakia.

\begin{tabular}{|c|c|c|c|c|c|c|}
\hline Years & 2007 & 2008 & 2009 & 2010 & 2011 & $\begin{array}{c}\text { Change } \\
2011 / 2007\end{array}$ \\
\hline Slovakia & $\mathbf{2 6 5}$ & $\mathbf{2 8 5}$ & $\mathbf{2 9 3}$ & $\mathbf{3 0 7}$ & $\mathbf{3 2 4}$ & $\mathbf{2 1 , 9 \%}$ \\
\hline Region of Bratislava & 413 & 435 & 440 & 458 & 500 & $21,2 \%$ \\
\hline Region of Trnava & 298 & 319 & 329 & 344 & 365 & $22,2 \%$ \\
\hline Region of Trenèín & 259 & 280 & 287 & 301 & 318 & $22,7 \%$ \\
\hline Region of Nitra & 275 & 298 & 306 & 321 & 344 & $24,9 \%$ \\
\hline Region of Žilina & 228 & 247 & 256 & 270 & 288 & $26,4 \%$ \\
\hline Region of Banská Bystrica & 247 & 267 & 275 & 289 & 298 & $20,4 \%$ \\
\hline Region of Prešov & 205 & 222 & 229 & 240 & 250 & $22,1 \%$ \\
\hline Region of Košice & 234 & 251 & 256 & 268 & 275 & $17,7 \%$ \\
\hline
\end{tabular}

Source: own study based on the data of the Statistical Office of the Slovak Republic.

Fig. 1. Number of passenger cars per 1000 inhabitants in the regions of Slovakia in the years 2007-11.

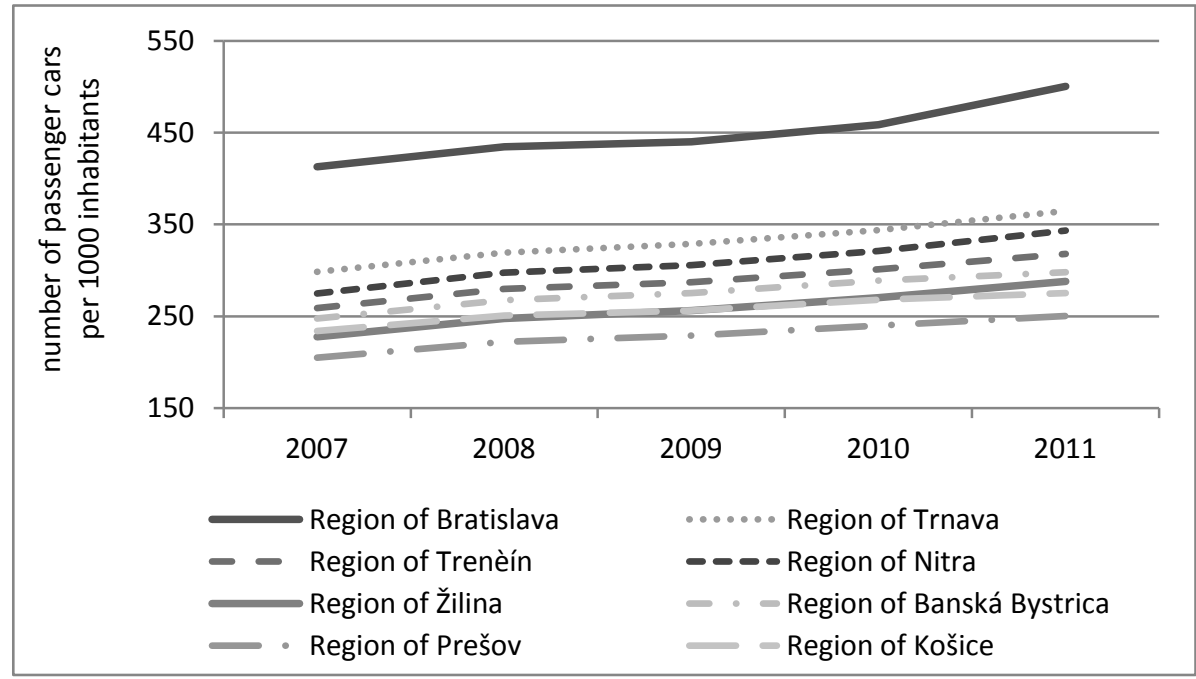

Source: own study.

\footnotetext{
${ }^{17}$ http://kurierkolejowy.eu/aktualnosci/9875/Trendy-w-transporcie-pasazerskim.html
} 
In the years from 2007 to 2011 the number of passenger cars per 1000 inhabitants in Slovakia was characterized by a constant upward trend. This trend can be described by a linear trend equation of the form:

$$
x_{t}=253,5+13,8 \cdot t+u_{1 t}
$$

where:

$\mathrm{x}_{\mathrm{t}}-$ the number of passenger cars per 1000 inhabitants,

$\mathrm{t}-$ the number of the next period of time (a year), $\mathrm{t}=1,2, \ldots, 5$,

$\mathrm{u}_{1 \mathrm{t}}-$ residual component of the model.

On the basis of equation (1), for which the coefficient of determination is 0.984 , it is concluded that the number of passenger cars per 1000 inhabitants increased year on year by an average of 13.8 of the vehicle. During the studied period the increase was almost $22 \%$, which gives an average annual rate of change of $5.1 \%$.

While studying the evolution of the number of passenger cars per 1000 inhabitants in the regions of Slovakia it was stated that:

- during the research period in all regions regular upward trend performed (Fig. 1);

- depending on the region, throughout the period the increases ranged from $17.7 \%$ to $26.4 \%$;

- clearly the largest index value was maintained in the region of Bratislava (about 100\% more than the value of the smallest - in the Prešov Region).

In turn, the data on the number of passengers per 1000 population were shown in table 2 .

Table 2. Number of passengers per 1000 inhabitants in Slovakia.

\begin{tabular}{|c|c|c|c|c|c|c|}
\hline Years & 2007 & 2008 & 2009 & 2010 & 2011 & $\begin{array}{c}\text { Change } \\
2011 / 2007\end{array}$ \\
\hline Slovakia & $\mathbf{7 1 ~ 2 1 6}$ & $\mathbf{6 7 5 3 5}$ & $\mathbf{5 9 5 6 6}$ & $\mathbf{5 7 5 3 5}$ & $\mathbf{5 5 4 3 3}$ & $\mathbf{- 2 2 , 2 \%}$ \\
\hline Region of Bratislava & 27984 & 27464 & 25248 & 25049 & 25660 & $-8,3 \%$ \\
\hline Region of Trnava & 63080 & 59062 & 51693 & 50503 & 49414 & $-21,7 \%$ \\
\hline Region of Trenèín & 103864 & 98608 & 88745 & 86013 & 81190 & $-21,8 \%$ \\
\hline Region of Nitra & 82208 & 85091 & 77447 & 76433 & 72763 & $-11,5 \%$ \\
\hline Region of Žilina & 90450 & 84692 & 75848 & 72081 & 72136 & $-20,2 \%$ \\
\hline Region of BanskáBystrica & 90866 & 82217 & 70455 & 69026 & 64672 & $-28,8 \%$ \\
\hline Region of Prešov & 61220 & 57055 & 49075 & 47529 & 44582 & $-27,2 \%$ \\
\hline Region of Košice & 52303 & 48571 & 41172 & 37610 & 37000 & $-29,3 \%$ \\
\hline
\end{tabular}

Source: own study based on the data of the Statistical Office of the Slovak Republic.

In the period from 2007 to 2011 in Slovakia there was a consistent trend of decreasing the number of passengers per 1000 inhabitants. Throughout the period, the decrease was $22.2 \%$ (year-on-year average of $6.1 \%$ ).

This trend can be described by a linear trend equation in the form:

$$
y_{t}=74727-4156 \cdot t+u_{2 t}
$$

where:

$\mathrm{y}_{\mathrm{t}}-$ the number of passengers per 1000 inhabitants,

$\mathrm{t}$ - the number of the next period of time (a year), $\mathrm{t}=1,2, \ldots, 5$,

$\mathrm{u}_{2 \mathrm{t}}$ - residual component of the model.

Equation (2) shows that the number of passengers per 1000 inhabitants decreased from year to year by average of 4156 . This equation describes the variation trend of the 
number of passengers per 1000 inhabitants in almost 94\% (coefficient of determination $\mathrm{R}^{2}$ $=0.937$ ).

The equation of the trend indicates the trend of development but does not explain its cause. However, this is not difficult to find the cause. Opposing trends in the number of cars and the number of passengers per 1000 inhabitants for Slovakia in the research period can be explained by the existence of a strong linear correlation between these variables (correlation coefficient is equal to -0.94). This relationship can be described by the following linear regression equation:

$$
y_{t}=147914-290,4 \cdot x_{t}+u_{3 t}
$$

where:

$\mathrm{y}_{\mathrm{t}}-$ the number of passengers per 1000 inhabitants,

$\mathrm{x}_{\mathrm{t}}-$ the number of passenger cars per 1000 inhabitants,

$\mathrm{u}_{3 \mathrm{t}}$ - residual component of the model.

Equation (3) indicates that the increase in the number of passenger cars per 1000 inhabitants by 10 pieces causes a decrease in the number of transports per 1000 inhabitants by average 2904. Average error of estimate is about 2,647, which is slightly more than $4 \%$ of the average number of passengers. This model explains in almost $89 \%$ changes in passenger sizes in Slovakia in the years 2007-11.

Fig. 2. Number of passengers per 1000 inhabitants in the regions of Slovakia in the years 2007-2011.

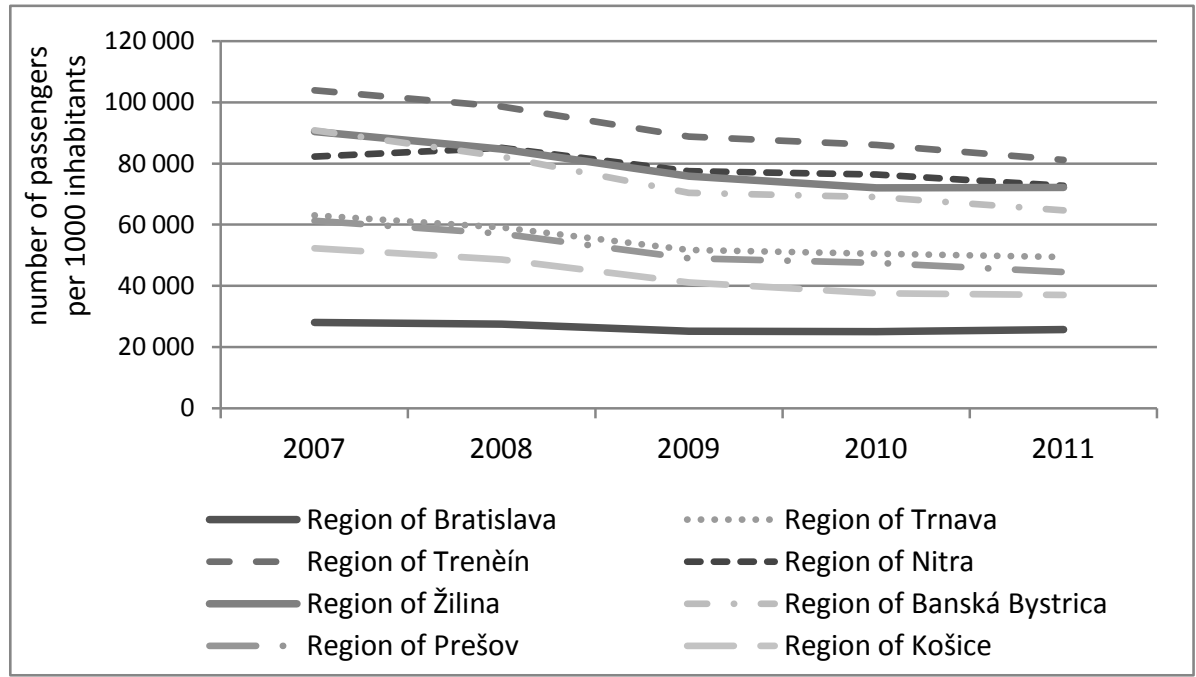

Source: own study

When comparing the regions of Slovakia due to the number of passengers per 1000 inhabitants, one can see that:

- in all regions a regular decreasing trend was observed during the period of time (Fig. 2);

- there are large differences between regions that are systematically reduced; the smallest transport size in the Region of Bratislava, and the largest - in the Region of Trenèin (in 2007 year - 271\% more than in the Region of Bratislava, and in 2011 only $216 \%$ more); 
- there are large differences in the rate of decline between regions, we can distinguish three groups:

○ smallest declines (approximately10\%): Region of Bratislava, Nitra Region;

- medium-sized drops (about 21\%): Region of Trnava, Region of Trenèín, Region of Žilina;

○ the largest decreases (approximately 28\%): Region of Banská Bystrica, Prešov Region, Region of Košice.

\section{DATA ANALYSIS FOR POLAND}

The same tests as for Slovakia were performed for Poland. The corresponding data are shown in Tables 3 and 4.

Table 3. Statistical data for Poland.

\begin{tabular}{|l|c|c|c|c|c|c|}
\hline years & 2007 & 2008 & 2009 & 2010 & 2011 & $\begin{array}{c}\text { Change } \\
2011 / 2007\end{array}$ \\
\hline $\begin{array}{l}\text { no. of passenger cars } \\
\text { per 1000 inhabitants }\end{array}$ & 383 & 422 & 432 & 451 & 470 & $22,9 \%$ \\
\hline $\begin{array}{l}\text { no. of passengers } \\
\text { per 1000 inhabitants }\end{array}$ & 106990 & 106619 & 99011 & 102225 & 100972 & $-5,6 \%$ \\
\hline
\end{tabular}

Source: own study based on CSO data.

In the years 2007-11 the number of passenger cars per 1000 inhabitants in Poland was constantly growing. This trend can be described by a linear trend equation of the form:

$$
x_{t}=370,1+20,5 \cdot t+u_{4 t}
$$

where:

$\mathrm{x}_{\mathrm{t}}-$ the number of passenger cars per 1000 inhabitants,

$\mathrm{t}$ - the number of the next period of time (a year), $\mathrm{t}=1,2, \ldots, 5$,

$\mathrm{u}_{4 \mathrm{t}}-$ residual component of the model.

Based on the equation (4) it was concluded that the number of passenger cars per 1000 inhabitants increased year by year by an average of 20.5 of the vehicle. The coefficient of determination is 0.959 which indicates a high consistency with the data model. During all the studied period the increase was almost $23 \%$, which gives an average annual rate of change of $5.3 \%$.

At the same time in Poland there was a decrease in the number of passengers per 1000 inhabitants. Throughout the period, the decline amounted to $5.6 \%$ (year-on-year average of $1.4 \%$ ). This trend was brought closer with the linear trend equation of the form:

$$
y_{t}=108093-1643 \cdot t+u_{5 t}
$$

where:

$\mathrm{y}_{\mathrm{t}}-$ the number of passengers per 1000 inhabitants,

$\mathrm{t}$ - the number of the next period of time (a year), $\mathrm{t}=1,2, \ldots, 5$,

$\mathrm{u}_{5 \mathrm{t}}$ - residual component of the model.

Model (5) shows that the number of passengers per 1000 inhabitants decreased from year to year by average of 1643 . This trend equation describes the variation of the number of passengers per 1000 inhabitants in almost 55\% (coefficient of determination $\mathrm{R}^{2}$ $=0.545$ ). 
Like for Slovakia, also for Poland the linear regression equation was determined, which allows to estimate the size of the passenger transport based on the number of cars:

$$
y_{t}=135389-74,6 \cdot x_{t}+u_{6 t}
$$

where:

$\mathrm{y}_{\mathrm{t}}$ - the number of passengers per 1000 inhabitants,

$\mathrm{x}_{\mathrm{t}}-$ the number of passenger cars per 1000 inhabitants,

$\mathrm{u}_{6 \mathrm{t}}-$ residual component of the model.

Equation (6) indicates that the increase in the number of passenger cars per 1000 inhabitants by 10 pieces causes a decrease in the number of transports per 1,000 inhabitants by average about 746 . The average error of estimate is about 2,890 , which represents only $2.8 \%$ of the average number of passengers, which proves the high compatibility of the model with the data. This model explains in almost $50 \%$ the changes in passenger sizes in Poland in the years 2007-11.

Table 4. Statistical data for provinces in Poland.

\begin{tabular}{|c|c|c|c|c|c|c|}
\hline & \multicolumn{3}{|c|}{$\begin{array}{c}\text { no. of passengers } \\
\text { per 1000 inhabitants }\end{array}$} & \multicolumn{3}{c|}{$\begin{array}{c}\text { no. of passenger cars } \\
\text { per 1000 inhabitants }\end{array}$} \\
\hline Provinces & 2007 & 2011 & $\begin{array}{c}\text { change } \\
\text { in \% }\end{array}$ & 2007 & 2011 & $\begin{array}{c}\text { change } \\
\text { in \% }\end{array}$ \\
\hline Lower Silesian & 86854 & 74079 & $-14,7$ & 381,2 & 476,4 & 25,0 \\
\hline Kuyavian-Pomeranian & 91477 & 82932 & $-9,3$ & 355,2 & 461,5 & 29,9 \\
\hline Lublin & 44779 & 45062 & 0,6 & 347,2 & 438,3 & 26,3 \\
\hline Lubusz & 49579 & 41052 & $-17,2$ & 402,4 & 487,0 & 21,0 \\
\hline Łódź & 78642 & 85120 & 8,2 & 373,2 & 473,2 & 26,8 \\
\hline Lesser Poland & 159805 & 118830 & $-25,6$ & 376,2 & 451,3 & 20,0 \\
\hline Masovian & 185796 & 210644 & 13,4 & 440,4 & 519,1 & 17,9 \\
\hline Opole & 29891 & 27570 & $-7,8$ & 414,2 & 511,6 & 23,5 \\
\hline Subcarpathian & 32423 & 25378 & $-21,7$ & 343,1 & 417,6 & 21,7 \\
\hline Podlaskie & 98097 & 89850 & $-8,4$ & 340,2 & 409,2 & 20,3 \\
\hline Pomeranian & 149261 & 128554 & $-13,9$ & 385,8 & 467,9 & 21,3 \\
\hline Silesian & 135579 & 123110 & $-9,2$ & 374,0 & 463,3 & 23,9 \\
\hline Holy Cross & 59580 & 36716 & $-38,4$ & 353,6 & 440,0 & 24,4 \\
\hline Warmian-Masurian & 49783 & 43356 & $-12,9$ & 332,6 & 418,3 & 25,8 \\
\hline Greater Poland & 86510 & 84051 & $-2,8$ & 437,9 & 531,6 & 21,4 \\
\hline West Pomeranian & 109910 & 105624 & $-3,9$ & 337,2 & 437,5 & 29,8 \\
\hline
\end{tabular}

Source: own study based on CSO data. 
Fig. 3. Number of passenger cars per 1000 inhabitants in Polish provinces.

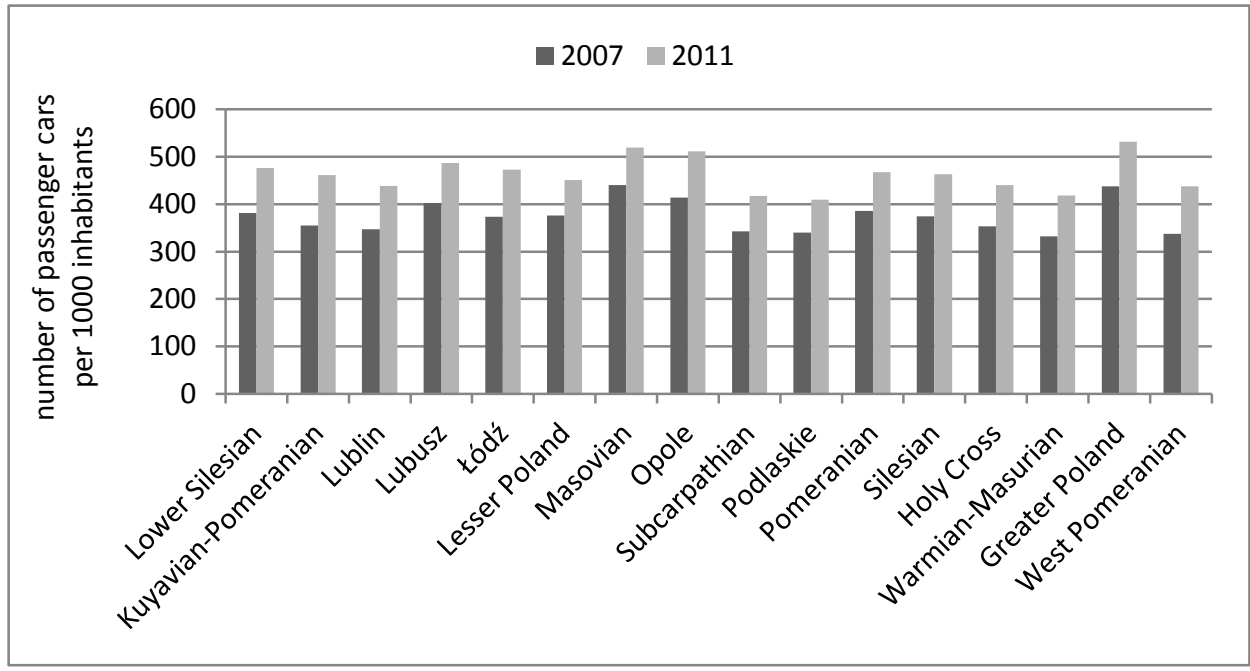

Source: own study

While observing how the number of passenger cars per 1000 inhabitants in Polish provinces shaped (Fig. 3), it was discovered that:

- in all regions a regular upward trend was noticed;

- the highest value of the index is in Masovian and Greater Poland, about 30\% higher than the minimum;

- in different regions in the research period the increases ranged from $17.9 \%$ to $29.9 \%$.

Fig. 4. Number of passengers per 1000 inhabitants in Polish provinces.

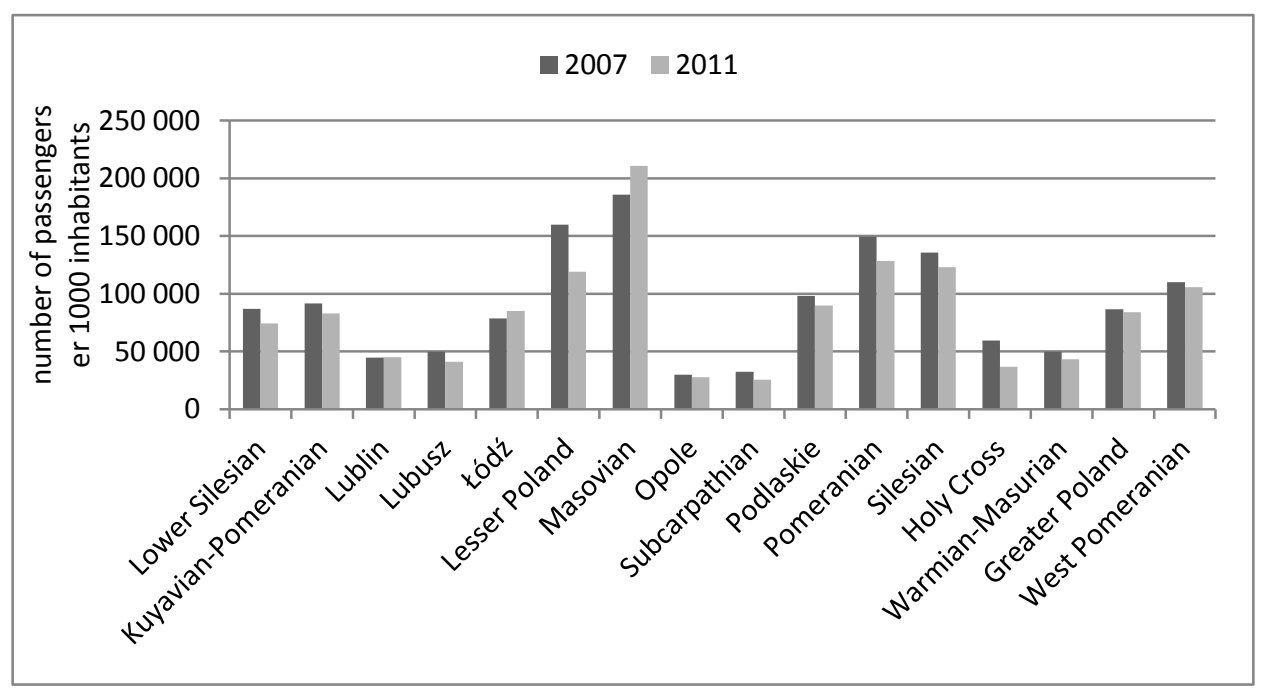

Source: own study 
When comparing the various Polish regions due to the number of passengers per 1000 inhabitants it can be observed (Fig. 4) that:

- between regions there are significant differences in the sizes of transport: the smallest value in Opole and Subcarpathian provinces, the largest in Masovian;

- in 13 regions a decline was recorded, while in the three the growth rate, which is dominated by a decreasing trend;

- in the research period the changes in different regions ranged widely, from a decline of $38.4 \%$ for the Holy Cross to increase by $13.4 \%$ in Masovian province;

- changes are not regular - in many regions the increase in the index in the selected years was recorded.

\section{CONCLUSIONS FROM DATA ANALYSIS}

In chapters 4 and 5 the analysis of data on public transport and automotive index in Poland and Slovakia was done. In order to determine similarities or differences in the changes taking place on the public transport market the comparison of relations between countries was done. By comparing how the variables shaped in both countries in the years 2007-11, one may conclude that:

- in all regions of the two countries the number of passenger cars per 1000 inhabitants was characterized by a constant upward trend, resulting in the occurrence of similar trends in the country (Figure 5);

- the annual average growth rate in the two countries remained at a similar level $(5.1 \%$ in Slovakia and $5.3 \%$ in Poland);

- in the analyzed period, the number of passenger cars per 1000 inhabitants in Poland was approximately $46 \%$ higher than in Slovakia and this difference did not change;

- the relative differences in the number of cars between regions in Slovakia was much higher than in Poland (coefficient of variation in individual years was approximately $21 \%$ for Slovakia and about $8 \%$ for Poland);

Fig. 5. Change in the number of passenger cars per 1000 inhabitants in the years 2007-11.

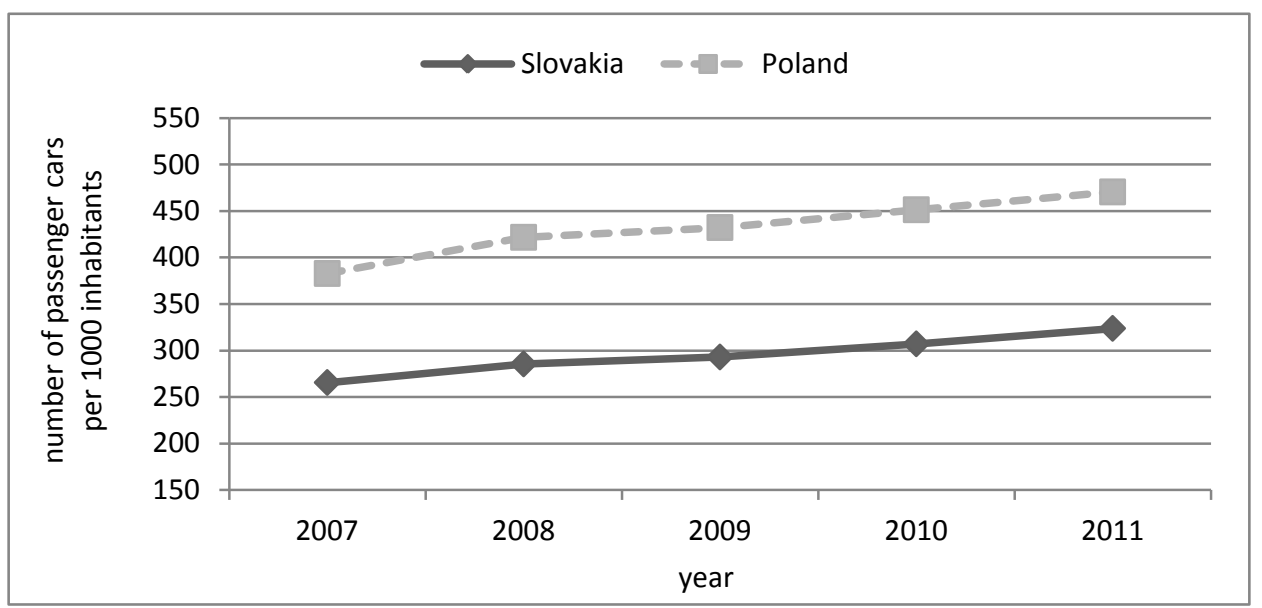

Source: own study. 
Fig. 6. Change in the number of passengers per 1000 inhabitants in the years 2007-11.

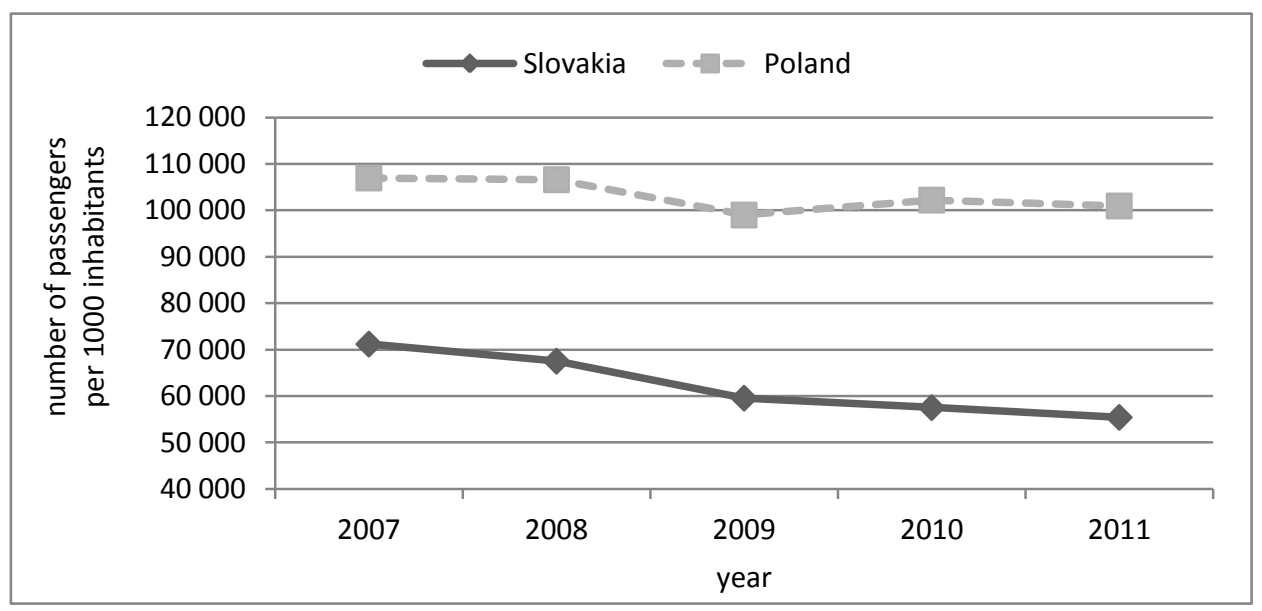

Source: own study.

- in all regions of Slovakia and in most regions of Poland there was a reduction in the number of passengers per 1000 inhabitants, which resulted in the occurrence of downward trends in both countries (Figure 6), the average annual rate of decline in Poland (1.4\%) was significantly lower than in Slovakia $(6.1 \%)$;

- throughout the period the disparity between the two countries in the number of passengers per 1000 inhabitants increased; in 2007 year $50.2 \%$ more passengers were carried than in Slovakia, and in 2011 up to $82.1 \%$ more;

- the relative differences in the size of passenger transport between the regions of Slovakia was much lower than in Poland (coefficient of variation in individual years was approximately $33 \%$ for Slovakia, while the coefficient for Poland rose from 50\% to $57 \%$ ).

In conclusion, one can say that the statistics in both countries confirm the existence of a link between the number of cars and the size of passenger transport. This relationship for each country can be expressed with high accuracy by the linear regression equation. Moreover, one can notice the presence in the years 2007-11 similar trend of the tested variables in the regions, which translates into analogous trends for the country. In addition to these similarities, one can notice the differences between regions and countries which are expressed mainly in the values of variables, and the pace of change.

The research done and the presented models, except that they illustrate and explain the changes, can be also used for forecasting. The demand for forecasting for urban transport services, however, is a difficult task. In addition to the saturation level of the individual means of transport the communication mobility is also important. Communication mobility of the population ${ }^{18}$ depends on the number of inhabitants and their characteristics (occupational structure, place of employment or age), and the degree of industrialization of the city (the specifics of the urban area). The materials available do not include statistical data that would describe current trends occurring in these interesting areas.

\footnotetext{
${ }^{18}$ K. Hebel, Potrzeby przewozowe jako determinanty popytu na ustugi transportu miejskiego, „Przegląd Komunikacyjny", nr 12, 2007, s. 26-29.
} 
Changes in both countries are similar to the trends that occurred in the "old" EU countries several decades ago and are therefore inevitable. Knowledge of these relationships may, however, allow faster achievement of the desired target state in the form of re-development of public transport in the new form.

\section{REFERENCES}

[1] Beim M., Europejskie trendy $w$ transporcie miejskim $i$ regionalnym, [w:] Materiaty $z$ konferencji „Przyszłość transportu publicznego - perspektywa regionalna i europejska” (Wrocław, 5 XII 2012), http://www.wspolnesprawy.pl/uploads/beim_trendy_ w_transporcie.pdf

[2] Bartosiński T., Cel i zakres ustawy o publicznym transporcie zbiorowym, [w:] Materiały z konferencji „Plan transportowy w ustawie o publicznym transporcie zbiorowym” (Warszawa, 25 XI 2009), SITK Oddział w Warszawie, Warszawa 2009, http://siskom.waw.pl/nauka/ konferencje/20091125/publikacja_calosc.pdf

[3] Costa Á., Fernandes R., Urban public transport in Europe: Technology diffusion and market organization, "Transportation Research" Part A 46 (2012)

[4] Drewnowski A., Wysocka A., Możliwości rozwoju zintegrowanych systemów kolejowodrogowych pasażerskiego transportu regionalnego $w$ świetle nowej ustawy o publicznym transporcie zbiorowym, Zeszyty Naukowe Politechniki Śląskiej, Seria: Transport, z. 75, Gliwice 2012

[5] Gadziński J., Ocena dostępności komunikacji przestrzeni miejskiej na przykładzie Poznania, Bogucki Wydawnictwo Naukowe, Poznań 2010

[6] Hebel K., Potrzeby przewozowe jako determinanty popytu na ushugi transportu miejskiego, „Przegląd Komunikacyjny”, nr 12, 2007

[7] Malasek J., Pakiety wdrożeniowe koordynacji miejskiej polityki transportowej z polityka zagospodarowania przestrzennego, „Transport Miejski i Regionalny”, nr 12, 2011

[8] Mindur M., Transport pasażerski w Stanach Zjednoczonych $i$ Unii Europejskiej w latach 1990-2010, „Transport Miejski i Regionalny”, nr 7-8, 2011

[9] Opinion of the European Economic and Social Committee on transport in urban and metropolitan areas (exploratory opinion), TEN/276-CESE 615/2007, Brussels 2007

[10] Wilcox R. R., Applying Contemporary Statistical Techniques, Amsterdam: Academic Press, 2003

[11] Zdanowski W., Rozwój czy regres przyszłości transportu publicznego w Polsce i na Dolnym Śląsu w perspektywie 2020, Instytut Rozwoju i Promocji Kolei, Wrocław 2012

[12] http://kurierkolejowy.eu/aktualnosci/9875/Trendy-w-transporcie-pasazerskim.html

[13] http://portal.statistics.sk/showdoc.do?docid=359

[14] http://www.stat.gov.pl/gus

\section{WIELKOŚĆ PUBLICZNYCH PRZEWOZÓW PASAŻERSKICH A LICZBA SAMOCHODÓW OSOBOWYCH W POLSCE I NA SLOWACJI}

Wzrost zamożności społeczeństwa prowadzi do zwiększania liczby posiadanych dóbr. $\mathrm{W}$ obecnych czasach jednym z podstawowych dóbr staje się własny środek transportu. Począwszy od drugiej połowy XX wieku jako własny środek transportu upowszechnił się w Europie samochód osobowy. Rozwój motoryzacji jest czynnikiem decydującym o zachodzących zmianach w sposobie zaspokajania potrzeb transportowych. Wzrost liczby samochodów osobowych w społeczeństwie zwykle prowadzi do zmniejszonego popytu na usługi transportu zbiorowego. 
W pracy dokonano porównania wielkości publicznych przewozów pasażerskich oraz liczby samochodów osobowych w dwóch graniczących ze sobą krajach, to jest w Polsce i na Słowacji. W przeprowadzonych analizach wykorzystano dostępne dane zgromadzone przez urzędy statystyczne obu krajów. Dane te obejmowały lata 2007-11 i dotyczyły województw w Polsce i regionów na Słowacji W celu porównania ze sobą badanych zmiennych dane te odniesione zostały do wielkości populacji w poszczególnych regionach.

Do badania związków pomiędzy zmiennymi zastosowano analizę korelacji i regresji liniowej. Przeprowadzona analiza wskazuje, że wzrost wskaźnika motoryzacji przyczynił się do spadku liczby publicznych przewozów pasażerskich w obu krajach. Dla każdego kraju związek ten opisano liniowym równaniem regresji. Ponadto wyznaczono dla obu krajów liniowe równania trendów badanych zmiennych oraz wykazano wystepowanie analogicznych trendów w regionach. Pokazano również pewne różnice pomiędzy regionami i krajami, które wyrażają się głównie w wartościach zmiennych oraz w tempie zachodzących zmian.

Słowa kluczowe: publiczne przewozy pasażerskie, samochód osobowy, województwo, zmienne, analiza korelacji i regresji liniowej.

\section{DOI: 10.7862/rz.2013.mmr.35}

Tekst złożono w redakcji: wrzesień 2013

Przyjęto do druku: wrzesień 2013 